\title{
RANGE EXTENSION FOR THE WHITE-NOSED COATI (NASUA NARICA) IN SOUTHEASTERN GUANAJUATO, MÉXICO
}

\author{
María Eugenia Espinosa-Flores ${ }^{1,2}$ and Carlos A. López-González ${ }^{1}$
}

\begin{abstract}
AвstRact.-We report the first photographic record of the white-nosed coati (Nasua narica) in the southeastern portion of the state of Guanajuato. Although this species is considered abundant and widely distributed in México, Guanajuato is not considered part of its current distribution. Because of the lack of records in surrounding areas, it is not possible to determine if there is an existing linkage to other populations. Thus, it is imperative to continue monitoring this species in the region to identify and assess the connectivity of other established populations and to ensure the species' long-term conservation.
\end{abstract}

Resumen.-Reportamos los primeros registros fotográficos del coatí de nariz blanca (Nasua narica) en la porción Sureste del estado de Guanajuato. A pesar de que ésta especie es considerada abundante y ampliamente distribuida en México, Guanajuato no es considerado como parte de su distribución actual. Debido a la falta de registros en áreas adyacentes no es posible determinar si existe conectividad con otras. Por lo tanto, es necesario continuar con los monitoreos de la especie en la región para poder identificar otras poblaciones establecidas y asegurar la conectividad que permita su conservación a largo plazo.

The procyonid genus Nasua contains 2 species: Nasua nasua and Nasua narica (Wilson and Reeder 2005). The latter, known as the white-nosed coati, is distributed from the southwestern region of the United States into Central America (Gompper 1995). In México, this species has been documented throughout the country except for on the peninsula of Baja California and in the central highlands and is considered common in the coastal slopes along the Pacific Ocean and the Gulf of México (Valenzuela 1998). The species has been associated most frequently with seasonal tropical forests, pine forests, pine-oak forests and scrublands at altitudes ranging from sea level up to $2900 \mathrm{~m}$. There are 2 documented records of the species in northeastern Guanajuato (Sánchez 2014) although compendium studies (Hall 1981, Ceballos and Arroyo-Cabrales 2012) do not recognize the white-nosed coati as part of the fauna of the state. Furthermore, available records of terrestrial mammals from the CONABIO (Comisión Nacional para el Conocimiento y Uso de la Biodiversidad) do not include the white-nosed coati as present in Guanajuato. Espinoza-García et al. (2014) discussed the potential distribution of the species in northeastern México, which included a small portion of northeastern Guanajuato, and mentioned the presence of recent records; however, location data and type of documentation associated with these records were not provided. In another report, Villaseñor (2008) included the South American coati (Nasua nasua) in an inventory of mammalian species recorded in Sierra de los Agustinos of Guanajuato, but this record is clearly a misidentification because this species is restricted to South America. In addition, all species records of medium- and large-sized mammals from this study were obtained only from interviews with local inhabitants and from spoor (e.g., scats, tracks) without specimen-based, photographic, or visual identification of species.

In the present study, we conducted a survey to determine the species richness of terrestrial mammals in 12 localities of southeastern Guanajuato using 5 camera traps (Wildview TK30, Stealth Cam, LLC, Grand Prairie, Texas, USA) per locality for a total of 60 cameras. Five cameras were placed at each site with one camera in the center and the others orientated to the 4 cardinal points, each separated by an average distance of $500 \mathrm{~m}$. The activity period of the cameras was $12 \mathrm{~d}$ with a total sampling effort of 58 camera trap-nights.

On 19 February 2014, we obtained 3 photographic records of the white-nosed coati (Fig. 1).

\footnotetext{
${ }^{1}$ Laboratorio de Zoología, Facultad de Ciencias Naturales, Universidad Autónoma de Querétaro. Av. De las Ciencias S/N, Col. Juriquilla, Santiago de Querétaro, México 76230.

${ }^{2}$ E-mail: eugeniaursusespinosa@gmail.com
} 


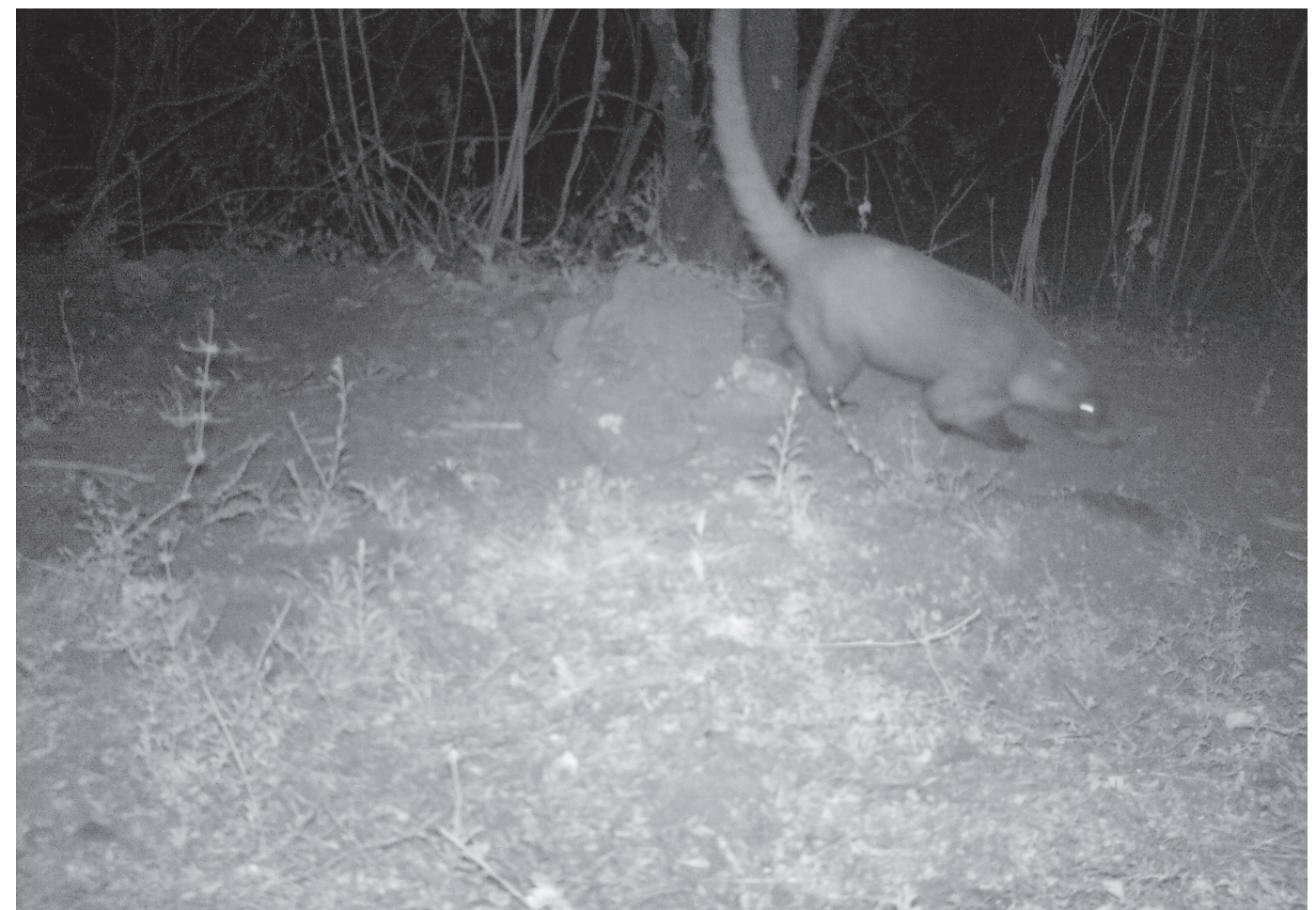

Fig. 1. Photographic record of the white-nosed coati (Nasua narica).

Records were obtained in the municipality of Tarimoro within the State Natural Protected Area of Sierra de los Agustinos, approximately $2.5 \mathrm{~km}$ from the community of La Concepción at an elevation of $2015 \mathrm{~m}$. Vegetation type at the study site is considered tropical scrub, with dominant tree species being Acacia farnesiana, Acacia pennatula, Ipomea murucoides, Bursera cuneata, Lysiloma microphylla, and pochoe (Ceiba aesculifolia) (Rzedowski and Calderón de Rzedowski 1987, Zamudio 2012). Annual precipitation in the area varies between $600 \mathrm{~mm}$ and $1200 \mathrm{~mm}$ (Zamudio 2012). Other mammalian species recorded at the site included ring-tailed cat (Bassariscus astutus), American hog-nosed skunk (Conepatus leuconotus), hooded skunk (Mephitis macroura), southern spotted skunk (Spilogale angustifrons), eastern cottontail (Sylvilagus floridanus), and gray fox (Urocyon cinereoargenteus). These were the only records of the white-nosed coati obtained while surveying the 12 localities.

Our photographs are the first photographic record for the species in this part of Guanajuato.
We considered that the absence of records in other parts of the region does not mean that the species is not present, but is more the consequence of very few wildlife survey efforts having been conducted in the region. Guanajuato is one of 3 states that have the fewest reported number of mammalian studies in México (Guevara-Chumacero et al. 2001). Such studies are especially lacking from southeastern Guanajuato, as greater conservation efforts have been focused on the northern portion of the state (Sánchez 2014), particularly the designated protected areas of Sierra de Lobos and the Reserva de la Biosfera de la Sierra Gorda. This is in part because of a trend to implement conservation efforts in forested environments (e.g., pine, oak, and oak-pine forests; Iglesias et al. 2008, Elizalde-Arellano et al. 2010, Cecaira-Ricoy et al. 2012, CharreMedellín et al. 2012, Iglesias et al. 2012), leaving other vegetation types such as tropical scrublands unstudied. However, these habitats are important refuges for biodiversity and it is important to monitor these habitats, especially 


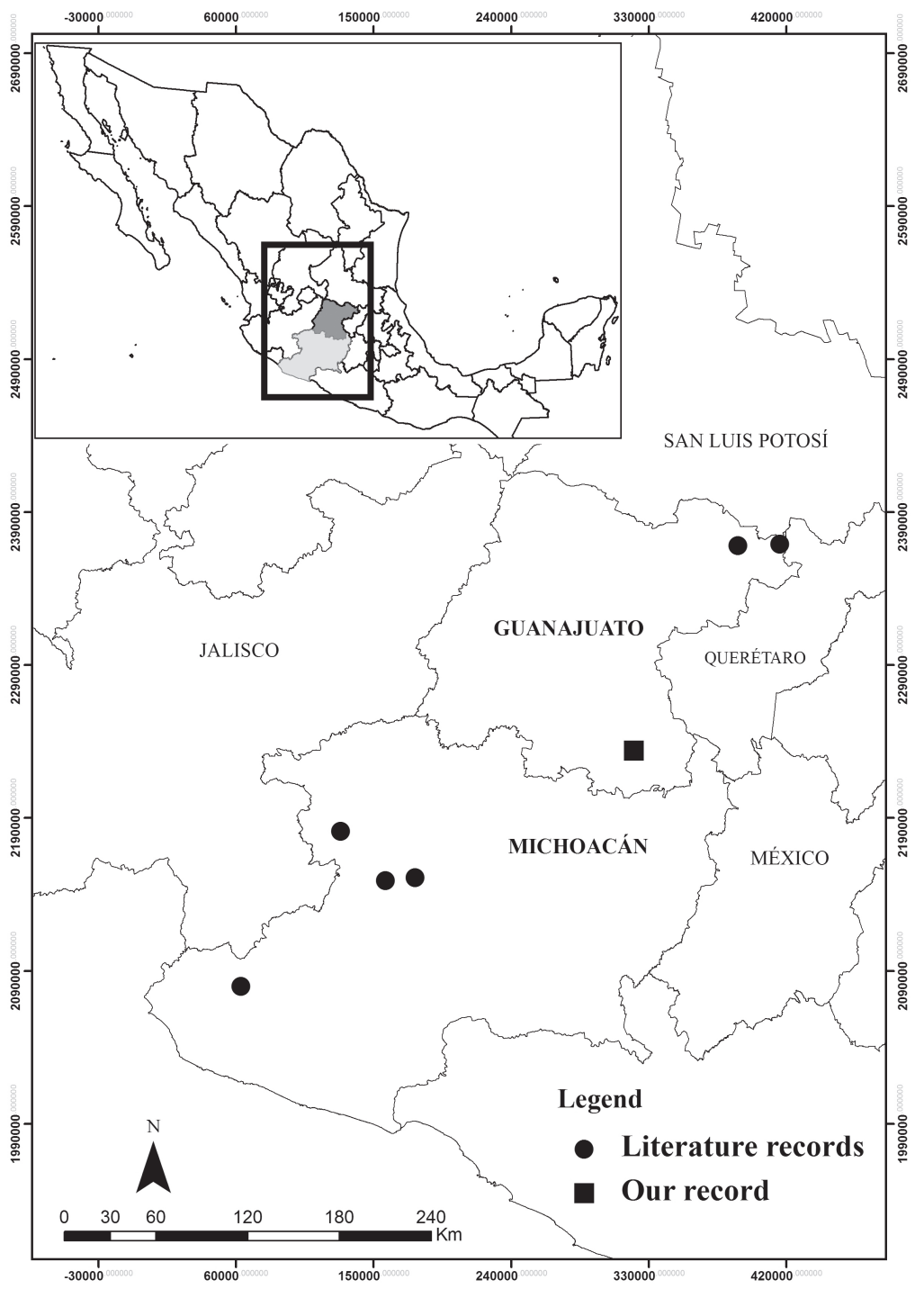

Fig. 2. Geographic location of the white-nosed coati records for Guanajuato and Michoacán, México.

in this region, as they represent relict tropical deciduous fragments which are highly threatened from the high rate of transformation to agricultural, urban, and industrial areas (Carranza-González 2005, Zamudio 2012).

Although the white-nosed coati is considered the most abundant carnivore in the tropical forests of the Americas (Valenzuela 2005), the presence of this species has not been verified for the southern portion of the state of Guanajuato (Ceballos and Arroyo-Cabrales 2012) and our photographic records are the first to confirm it in this area. Nearby known records of the species are located $165 \mathrm{~km}$ south of our record (Goldman 1951, Núñez-Garduño 2005 ) and $150 \mathrm{~km}$ north of our record (CharreMedellín et al. 2012, Iglesias et al. 2012; Fig. 2). Also, Leopold (1959) includes an occurrence record of white-nosed coati in his book on the wildlife of México, but locality is not provided. Our record extends the current knowledge of the distribution of the species in Guanajuato.

Because of the lack of records in the surrounding areas (Núñez-Garduño 2005), it is impossible to determine whether there is an existing linkage to other populations of the 
white-nosed coati in adjacent areas. It is possible that the species has been extirpated in many areas of Guanajuato because the area of tropical deciduous forest, one of the favored habitats of $N$. narica, has been drastically reduced from approximately $45 \%$ in the past to $<10 \%$ at present (Zamudio 2012). It is imperative to continue the monitoring of this species in the region to identify and assess the connectivity of other established populations to ensure the species' long-term conservation.

We thank Fernando Espinosa, Fernanda Cruz, and Socorro Tafoya for their assistance during field work; Robert Jones for the review of this manuscript; the local inhabitants of La Concepción and El Fénix for their permission to work in the Sierra de los Agustinos; and the Consejo Nacional de Ciencia y Tecnología (CONACYT) for providing a graduate scholarship to MEEF.

\section{Literature Cited}

CarranZa-GonzÁLez, E. 2005. Conocimiento de la flora y la diversidad vegetal del estado de Guanajuato, México. Flora del Bajío y de Regiones Adyacentes 21:1-17.

Ceballos, G., and J. Arroyo-Cabrales. 2012. Lista actualizada de los mamíferos de México 2012. Revista Mexicana de Mastozoología Nueva Época 2:27-80.

CEcaira-Ricoy, R., J.A. Iglesias-HernándeZ, J.F. CharReMedellín, R. Bolaños-Martínez, G.E. MagañaCota, V. SÁnChEZ-Cordero, E. Kato-Miranda., AND FJ. Botello-López. 2012. Registro notable de tres especies de mamíferos en la Reserva de la Biosfera Sierra Gorda de Guanajuato. Pages 280-282 in La Biodiversidad en Guanajuato: Estudio de Estado. Volume 2. Comisión Nacional para el Conocimiento y Uso de la Biodiversidad (CONABIO)/Instituto de Ecología del Estado de Guanajuato (IEE), México City and Guanajuato, México.

Charre-Medellín, J.F., V. SÁnchez-Cordero, G. MagañaCota, M. Álvarez-Jara., and F. Botello. 2012. Jaguarundi (Puma yagouaroundi) in Guanajuato, México. Southwestern Naturalist 57:117-118.

Elizalde-Arellano, C., J.C. López-Vidal, E.Q. UharT, J.I. Campos-Rodríguez., and R. HernándezARCIGA. 2010. Nuevos registros y extensiones de distribución de mamíferos para Guanajuato. Acta Zoológica Mexicana (n.s.) 26:73-98.

Espinoza-García, C.R., J.M. Martínez-Calderas, J. Palacio-Nuñez., and A.D. Hernández-Saint MarTin. 2014. Distribución potencial del coatí (Nasua narica) en el noreste de México: implicaciones para su conservación. Therya 5(1):331-345. dx.doi.org/ 10.12933/therya-14-195

Goldman, E.A. 1951. Biological investigations in México. Smithsonian Miscellaneous Collection 115:1-476.

Gomprer, M.E. 1995. Nasua narica. Mammalian Species 487:1-10.
Guevara-Chumacero, L.M., R. López-Wilchis., and V. SÁNCHEZ-CORDERO. 2001. 105 años de investigación Mastozoológica en México (1890-1995): Una revisión de sus enfoques y tendencias. Acta Zoológica Mexicana (n.s.) 83:35-72.

HaLl, R. 1981. The mammals of North America. Volume 1. John Wiley \& Sons, New York, NY. 690 pp.

Iglesias, J.A., V. SÁnchez-Cordero, G.E. Magaña-Cota, R. Bolaños, M. Aranda, R. Hernández., and F.J. BOTELLO-LóPEZ. 2008. Noteworthy records of margay, Leopardus wiedii and ocelot, Leopardus pardalis in the state of Guanajuato, México. Mammalia 72: 347-349.

Iglesias, J.A., V. Sánchez-Cordero, G.E. Magaña-Cota, R. Bolaños, M. Aranda, R. Hernández., and F.J. Botello-López. 2012. Diversidad de mamíferos medianos y grandes en el Municipio de Xichú. Pages 275-276 in La Biodiversidad en Guanajuato: Estudio de Estado. Volume 2. Comisión Nacional para el Conocimiento y Uso de la Biodiversidad (CONABIO)/Instituto de Ecología del Estado de Guanajuato (IEE), México City and Guanajuato, México.

LEOPOLD, A.S. 1959. Wildlife of Mexico: the game birds and mammals. University of California Press, Berkeley, CA. $581 \mathrm{pp}$.

NúÑEZ-GARDUÑO, A. 2005. Los mamíferos silvestres de Michoacán, diversidad, biología e importancia. Universidad Michoacana de San Nicolás de Hidalgo/ Secretaria de Difusión Cultural y Extensión Universitaria, Morelia, Michoacán, Mexico.

Rzedowski, J., AND G. CALderón de RZEdowsKi. 1987. El bosque tropical caducifolio de la región mexicana del Bajío. Trace 12:12-21.

Sánchez, O. 2014. Sinopsis de los mamíferos silvestres del estado de Guanajuato, México, y comentarios sobre su conservación. Therya 5(2):369-422. http://dx.doi.org/ 10.12933/therya-14-188

VALENZuela, D. 1998. Natural history of the white-nosed coati, Nasua narica, in a tropical dry forest of western Mexico. Revista Mexicana de Mastozoología 3:26-44.

Valenzuela, D. 2005. Tejón, Coatí. Nasua narica (Linnaeus, 1766). Pages 411-413 in G. Ceballos, and G. Oliva, editors, Los mamíferos silvestres de México. Fondo de Cultura Económica/CONABIO, México City, México.

Villaseñor, L.E. 2008. Diagnóstico ambiental del área de uso sustentable Sierra de los Agustinos, municipio de Acámbaro, Guanajuato. Ayuntamiento de Acámbaro, Guanajuato/Facultad de Biología de la Universidad Michoacana de San Nicolás de Hidalgo. Editorial Universitaria, Morelia, Michoacán, México.

Wilson, D.E., and D.A.M. ReEder. 2005. Mammal species of the world: a taxonomic and geographic reference. 3rd edition. Johns Hopkins University Press, Baltimore, MD. 2000 pp.

Zamudio, S. 2012. Diversidad de ecosistemas del Estado de Guanajuato. Pages 21-55 in La Biodiversidad en Guanajuato: Estudio de Estado. Volume 2. Comisión Nacional para el Conocimiento y Uso de la Biodiversidad (CONABIO)/Instituto de Ecología del Estado de Guanajuato (IEE), México City and Guanajuato, México. 